\title{
Characterization of a new 2,4-dichlorophenoxyacetic acid degrading plasmid pEST4011: physical map and localization of catabolic genes
}

\author{
Andres A. Mäe,* Reet O. Marits, Nora R. Ausmees, Vita M. KôIv and Ain L. Heinaru \\ Institute of Molecular and Cell Biology at Tartu University, Estonian Biocentre, Vanemuise 46-127, Tartu EE2400, \\ Republic of Estonia
}

(Received 6 April 1992; revised 12 July 1993; accepted 26 July 1993)

\begin{abstract}
Plasmid pEST4011 enables Pseudomonas putida PaW85 to degrade 2,4-dichlorophenoxyacetic acid (2,4-D) and 3-chlorobenzoate (3-CBA). This new 2,4-D degradative plasmid has considerable homology with the regions of pJP4 containing the 2,4-D degradative genes $(t f d)$. Restriction fragment BamHI-B of plasmid pEST4011, which has homology with this region, was cloned into the broad-host-range vector pKT240 and studied in $P$. putida PaW85. Restriction mapping, hybridization analysis and enzyme assays established the location of the genes for 2,4-D monooxygenase $(t f d A)$, 2,4-dichlorophenol hydroxylase $(t f d B)$, chlorocatechol 1,2-dioxygenase $(t f d C$ ) and the $t f d R$ and $t f d S$ regulatory genes on this fragment. Plasmid pEST4012 is a derivative of pEST4011 derived through the spontaneous deletion of a $42 \mathrm{kbp}$ DNA fragment, which results in the loss of the 2,4-D ${ }^{+}$and 3-CBA ${ }^{+}$ phenotype. We present here the physical maps of pEST4011 and pEST4012. In spite of the similarities in functions, the size (70 kbp), order of catabolic genes and restriction pattern of pEST4011 are clearly different from those of pJP4.
\end{abstract}

\section{Introduction}

Plasmids involved in the degradation of 2,4-dichlorophenoxyacetic acid $(2,4-D)$ have been under considerable investigation (Pemberton \& Fisher, 1977; Pierce et al., 1981; Amy et al., 1985; Chaudhry \& Huang, 1988). The 2,4-D degradative plasmid pJP4 from Alcaligenes eutrophus JMP134 (isolated in Australia) has become a model for the investigation of 2,4-D degradation (Don \& Pemberton, 1985; Don et al., 1985; Ghosal \& You, 1988, 1989; Harker et al., 1989; Kaphammer \& Olsen, 1990; Kaphammer et al., 1990; Perkins et al., 1990). A second plasmid, pRC10, present in a 2,4-D-degrading Flavobacterium sp. isolated in the USA, has also been characterized in detail (Chaudhry \& Huang, 1988). Little information is, however, available on the nature and physical structure of other 2,4-D degradative plasmids.

*Author for correspondence. Present address: Department of Molecular Genetics, Uppsala Genetic Centre, Swedish University of Agricultural Sciences, Box 7010, S-750 07 Uppsala, Sweden. Fax +46 18673279 .

Abbreviations: 2,4-D, 2,4-dichlorophenoxyacetic acid; 3-CBA, 3chlorobenzoate.
Despite differences in the size and restriction pattern of 2,4-D plasmids there is considerable homology between the 2,4-D degradative genes (Don \& Pemberton, 1981; Amy et al., 1985; Chaudhry \& Huang, 1988; Ditzelmüller et al., 1989). Comparison of other plasmids which determine the degradation of chlorinated compounds with pJP4 would be of great value in understanding the evolutionary process by which enzymes with novel specificities are evolved by bacteria and how they have spread amongst bacteria.

Recently, we isolated from 2,4-D-pretreated soils in Estonia several plasmid-containing strains with the ability to degrade 2,4-D. Restriction analysis revealed that they all harboured an identical $78 \mathrm{kbp}$ plasmid, designated pEST4002 (Ausmees \& Heinaru, 1990).

In this paper, we present the physical maps of the $70 \mathrm{kbp}$ plasmid pEST4011, a derivative of pEST4002 which encodes enzymes for the catabolism of 2,4-D, and pEST4012, a spontaneous 2,4- $\mathrm{D}^{-}$derivative of pEST4011, which has $42 \mathrm{kbp}$ deleted. DNA-DNA hybridization showed extensive homology between the catabolic regions of $\mathrm{pJP} 4$ and $\mathrm{pEST} 4011$. The structural genes 2,4-D monooxygenase ( $t f d A$ ), chlorocatechol 1,2dioxygenase $(t f d C)$, 2,4-dichlorophenol hydroxylase $(t f d B)$ and the regulatory genes $t f d R$ and $t f d S$ have been cloned and localized on pEST4011. 


\section{Methods}

Bacterial strains and plasmids. Bacterial strains and plasmids used or constructed in this study are described in Table 1.

Media and culture conditions. The complete medium was Luria broth (LB) and the minimal medium (MS) was M9 salts solution (Maniatis et al., 1982) supplemented with trace elements (Bauchop \& Elsden, 1960). Concentrated stock solution $\left(20 \mathrm{mg} \mathrm{m}^{-1}\right)$ of 2,4-D was prepared as the sodium salt and added to MS medium at a final concentration of from 4.0 to $20.0 \mathrm{~mm}$. Antibiotics were incorporated into LB medium at the following concentrations: $30 \mu \mathrm{g}$ amplicillin (Ap) $\mathrm{ml}^{-1}, 1000 \mu \mathrm{g}$ carbenicillin $(\mathrm{Cb}) \mathrm{ml}^{-1}, 1000 \mu \mathrm{g}$ streptomycin $(\mathrm{Sm}) \mathrm{ml}^{-1}$ and $25 \mu \mathrm{g}$ kanamycin

Table 1. Bacterial strains and plasmids

\begin{tabular}{|c|c|c|}
\hline Strain or plasmid & Relevant markers* & Source or reference \\
\hline \multicolumn{3}{|l|}{ E. coli } \\
\hline HB101 & $\begin{array}{l}\text { hsdS20 recAl3 ara- } 14 \\
\text { proA } 2 \text { lac } Y 1 \text { galK2 } \\
\text { rps } L 20 \text { xyl-5 } \mathrm{mtl}-1 \\
\text { supE44 }\end{array}$ & $\begin{array}{l}\text { Maniatis et al. } \\
\text { (1982) }\end{array}$ \\
\hline TG1 & & Gibson (1984) \\
\hline \multicolumn{3}{|l|}{ P. putida } \\
\hline PaW85 & $\begin{array}{l}\text { Prototroph; } \operatorname{Tn} 4652 \text { in } \\
\text { chromosome }\end{array}$ & Bayley et al. (1977) \\
\hline $\mathrm{PaW} 340$ & $\begin{array}{l}\mathrm{Sm}^{\mathrm{r}} \mathrm{Trp}^{-} ; \mathrm{Tn} 4652 \text { in } \\
\text { chromosome }\end{array}$ & Bayley et al. (1977) \\
\hline EST4021 & Prototroph; $2,4-\mathrm{D}^{+}$ & This study \\
\hline EST4022 & Prototroph; 2,4-D & This study \\
\hline \multicolumn{3}{|l|}{ A. eutrophus } \\
\hline JMP134 & Prototroph; 2,4- $\mathrm{D}^{+}$ & $\begin{array}{l}\text { Dr H.-J. } \\
\text { Knackmuss } \dagger\end{array}$ \\
\hline \multicolumn{3}{|l|}{ Pseudomonas sp. } \\
\hline EST4002 & Prototroph; $2,4-\mathrm{D}^{+}$ & $\begin{array}{l}\text { Ausmees \& Heinaru } \\
(1990)\end{array}$ \\
\hline \multicolumn{3}{|l|}{ Plasmids } \\
\hline pUC18 & Cloning vector $\left(\mathrm{Ap}^{r}\right)$ & $\begin{array}{l}\text { Yanisch-Perron et al. } \\
\text { (1985) }\end{array}$ \\
\hline pKT240 & Cloning vector $\left(\mathrm{Cb}^{r} \mathrm{Km}^{\mathrm{r}}\right)$ & $\begin{array}{l}\text { Bagdasarian et al. } \\
\text { (1983) }\end{array}$ \\
\hline pJP4 & $\begin{array}{l}\text { Plasmid from JMPI34 } \\
\left(2,4-\mathrm{D}^{+} \mathrm{Hg}^{\mathrm{r}} 3-\mathrm{CBA}^{\mathrm{r}}\right)\end{array}$ & $\begin{array}{l}\text { Don \& Pemberton } \\
\text { (1981) }\end{array}$ \\
\hline pEST4002 & $\begin{array}{l}\text { Plasmid from EST4002 } \\
\left(2,4-\mathrm{D}^{+} \text {; wild-type } 2,4-\mathrm{D}\right. \\
\text { plasmid) }\end{array}$ & $\begin{array}{l}\text { Ausmees \& Heinaru } \\
(1990)\end{array}$ \\
\hline pEST4011 & $\begin{array}{l}\text { Del. mutant of pEST4002 } \\
\left(2,4-\mathrm{D}^{+}\right)\end{array}$ & This study \\
\hline pEST4012 & $\begin{array}{l}\text { Del. mutant of pEST4002 } \\
\left(2,4-\mathrm{D}^{-}\right)\end{array}$ & This study \\
\hline pEST4013 & $\begin{array}{l}\text { pKT } 240 \text { carrying } 10.5 \mathrm{kbp} \\
\text { Bam HI fragment of } \\
\text { pEST4011 }\end{array}$ & This study \\
\hline pEST4014 & $\begin{array}{l}\text { pKT } 240 \text { carrying } 7.8 \mathrm{kbp} \\
\text { BamHI-EcoRI fragment } \\
\text { of pEST } 4013\end{array}$ & This study \\
\hline pEST4015 & $\begin{array}{l}\text { pKT } 240 \text { carrying } 4.5 \mathrm{kbp} \\
\text { BamHI-KpnI fragment } \\
\text { of pEST } 4013\end{array}$ & This study \\
\hline pEST4016 & $\begin{array}{l}\text { pKT } 240 \text { carrying } 2.5 \mathrm{kbp} \\
\text { XhoI fragment of } \\
\text { pEST } 4013\end{array}$ & This study \\
\hline
\end{tabular}

*Abbreviations: Ap, ampicillin; $\mathrm{Cb}$, carbenicillin; $\mathrm{Km}$, kanamycin; $\mathrm{Sm}$, streptomycin; $\mathrm{Hg}$, mercury; $\mathrm{Trp}^{-}$, requirement for tryptophan; 2,4- $\mathrm{D}^{+}$, ability to grow on 2,4-dichlorophenoxyacetic acid; 3-CBA ${ }^{+}$, ability to grow on 3-chlorobenzoate.

$\dagger$ Institut für Mikrobiologie der Universität Stuttgart, Germany.
(Km) $\mathrm{ml}^{-1}$. Pseudomonas strains were incubated at $30^{\circ} \mathrm{C}$ and Escherichia coli strains at $37^{\circ} \mathrm{C}$, respectively. Cultures $(30 \mathrm{ml})$ for enzyme assays were grown in MS medium supplemented with Casamino acids ( $0.3 \%$, w/v). 2,4-D and 2,4-dichlorophenol (2,4-DCP) were added to final concentrations of $0.025 \%(\mathrm{w} / \mathrm{v})$ and $0.007 \%(\mathrm{w} / \mathrm{v})$, respectively. After $4 \mathrm{~h}$ growth, a $30 \mathrm{ml}$ culture was used to inoculate $70 \mathrm{ml}$ of the same medium and allowed to grow to mid-exponential phase.

DNA transformation. For transformation of $P$. putida cells with plasmid DNA, we followed the method described by Bagdasarian \& Timmis (1982). Transformation of $E$. coli cells was as described by Hanahan (1983).

DNA isolation, analysis and manipulation. Plasmid DNA was isolated by the procedures of Hansen \& Olsen (1978) and Connors \& Barnsley (1982) and purified by ethidium bromide- $\mathrm{CsCl}$ density gradient centrifugation. DNA cleavage by restriction endonucleases, agarose gel electrophoresis and isolation of restriction fragments from low-melting agarose gels were performed as described by Maniatis et al. (1982). The DNA fragments were cloned in E. coli into pUC18 (Yanisch-Perron $e t$ al., 1985) and in P. putida into pKT240 (Bagdasarian et al., 1983). The sizes of DNA fragments in agarose gels were calculated by comparing their mobilities with fragments of plasmid pWW0 of known size (Downing \& Broda, 1979).

Southern blotting and hybridization. DNA fragments were separated on $1.0 \%(\mathrm{w} / \mathrm{v})$ agarose gels and transferred to nitrocellulose filters according to Southern (1975). DNA probes were labelled to a specific activity of $1-3 \times 10^{7}$ c.p.m. ( $\left.\mu \mathrm{g} \mathrm{DNA}\right)^{-1}$ by nick-translation (Maniatis et al., 1982).

Oxygen uptake assay. Activities of 2,4-D monooxygenase were measured by monitoring oxygen uptake in the presence of 2,4-D using a Clark oxygen electrode (Yellow Springs Instruments Co.) and the YSI model 5300 biological oxygen monitor. Reaction mixtures contained approximately $10^{8}$ washed cells $\mathrm{ml}^{-1}$ and $2.5 \mathrm{~mm}-2,4-\mathrm{D}$ in $100 \mathrm{~mm}$-potassium phosphate buffer ( $\mathrm{pH} 7 \cdot 6$ ). The endogenous oxygen uptake was measured for $4 \mathrm{~min}$ in the absence of substrate and the reaction was started by injecting $20 \mu \mathrm{l}$ of 2,4-D into the chamber. The oxygen uptake was monitored for $5 \mathrm{~min}$.

Extract preparation and enzyme assays. Cell extracts for 2,4dichlorophenol hydroxylase $(t f d B)$ and chlorocatechol 1,2-dioxygenase $(t f d C)$ assay were prepared by harvesting mid-exponential phase cultures by centrifugation at $8000 \mathrm{~g}$ for $10 \mathrm{~min}$. The cell pellets were washed with $10 \mathrm{ml} 100 \mathrm{~mm}$-potassium phosphate buffer $(\mathrm{pH} \mathrm{7.6)}$, centrifuged again and suspended in $5 \mathrm{ml} 100 \mathrm{~mm}$-potassium phosphate buffer (pH 7.6) containing $1 \mathrm{~mm}$-2-mercaptoethanol, $0.1 \mathrm{mm-EDTA}$ and $2 \mu \mathrm{M}$-flavin adenine nucleotide. Cell-free extracts were prepared and 2,4-DCP hydroxylase activity was determined by the procedure of Kaphammer \& Olsen (1990).

Chlorocatechol 1,2-dioxygenase assays were performed as described by Hageman (1966) using 3-methylcatechol as the substrate instead of chlorocatechols. P. putida PaW85 did not express catechol 1,2dioxygenase activity at detectable levels when grown in MS medium containing $0.3 \%$ Casamino acids with or without $2,4-\mathrm{D}$ or $2,4-\mathrm{DCP}$.

Protein concentrations were determined by the method of Bradford (1976).

\section{Results}

Characterization of Pseudomonas putida EST4021(pEST4011)

We have previously reported the isolation of a new 2,4-D degradative plasmid pEST4002 in Pseudomonas 


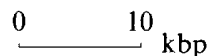

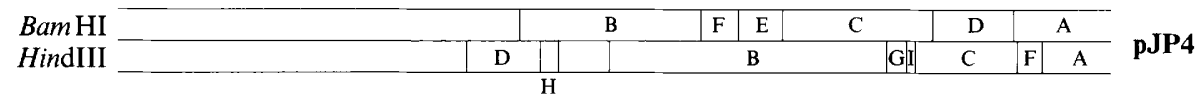

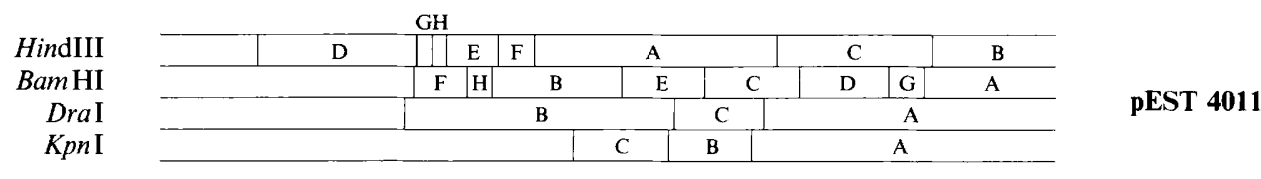

HindIII

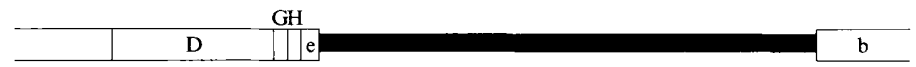

pEST 4012

Fig. 1. Restriction digest map of plasmids pJP4 (Kaphammer et al., 1990; Perkins et al., 1990), pEST4011 and pEST4012. The black box in plasmid pEST4012 shows the deleted region.

sp. EST4002 (Ausmees \& Heinaru, 1990), which could also utilize 3-CBA in addition to 2,4-D as a sole source of carbon. The growth characteristics are similar to those of A. eutrophus (Don \& Pemberton, 1981) which harbours plasmid pJP4 (Don \& Pemberton, 1985; Don et al., 1985). The $2,4-\mathrm{D}^{+}$phenotype was very unstable in EST4002 and similar isolates (results not presented). In EST $4002,80 \%$ of the cells had lost their ability to grow on 2,4-D after growth in a non-selective LB medium for $4 \mathrm{~h}$. In most cases the $2,4-\mathrm{D}^{-}$clones were either plasmid-free or contained a smaller plasmid, derived from pEST 4002 by a deletion of $20-30 \mathrm{kbp}$ (Ausmees \& Heinaru, 1990). Due to the instability of the 2,4- $\mathrm{D}^{+}$ phenotype and the difficulties with DNA extraction from the wild-type strains the exact location and size of the deletion was not determined.

To overcome the above difficulties pEST4002 was transferred by conjugation from EST4002 into the plasmid-free recipient strain $P$. putida PaW340. Restriction analysis showed that $2,4-\mathrm{D}^{+}$transconjugants of PaW340 contained a $70 \mathrm{kbp}$ plasmid pEST4011, which had lost a $7.8 \mathrm{kbp} E c o$ RI fragment present in pEST4002 (78 kbp).

P. putida strain PaW85 was transformed with pEST4011 and subcultured to obtain stable 2,4-D 3-CBA ${ }^{+}$transformants. A single plasmid, pEST4011 in strain EST4021 was detected. In batch cultures the growth rates of EST4021(pEST4011) were the same at 2,4-D concentrations between $4 \cdot 0-20 \cdot 0 \mathrm{~mm} ; 4 \mathrm{~mm}-2,4-\mathrm{D}$ $\left(1 \mathrm{mg} \mathrm{ml}^{-1}\right)$ was degraded within $14 \mathrm{~h}$ after a lag period of $1-3 \mathrm{~h}$.
In spite of its similar functions, the size $(70 \mathrm{kbp})$ and restriction pattern of plasmid pEST4011 (Fig. 1) are considerably different from those of pJP4 $(80 \mathrm{kbp})$.

In contrast to pEST4002 in EST4002, pEST4011 was relatively stable in EST4021. However, growth of EST4021 in LB medium for 30 generations resulted in a putative cured strain which had simultaneously lost its ability to grow on 2,4-D and 3-CBA. One 2,4-D strain. EST4022 did not revert to the $2,4-\mathrm{D}^{+}$phenotype at detectable levels $\left(<1\right.$ in $\left.10^{10}\right)$ and contained a $28 \mathrm{kbp}$ plasmid pEST4012. Five such $2,4-\mathrm{D}^{-} 3-\mathrm{CBA}^{-}$clones, isolated in separate experiments after prolonged growth of EST4021 in LB medium, contained plasmids with the same restriction patterns as pEST4012.

2,4-D monooxygenase, 2,4-DCP hydroxylase and chlorocatechol 1,2-dioxygenase activities were detected in EST4021(pEST4011), but not in EST4022(pEST4012). This suggests that the catabolic genes are located on the excised DNA segment.

\section{Physical maps of the plasmids pEST4011 and pEST4012}

By using restriction analysis, gene cloning and Southern hybridization a physical map of pEST4011 and pEST4012 was determined with restriction endonucleases BamHI, DraI, HindIII and KpnI (Fig. 1). Comparison of pEST4012 with pEST4011 indicates the excision of a $42 \mathrm{kbp}$ fragment and the restriction mapping reveals that the excised region is a continuous segment of the 2,4-D plasmid pEST4011. 


\section{Homology between pJP4 and pEST4011}

The homology between pEST4011 and the 2,4-D ${ }^{+}$ plasmid pJP4 was investigated by Southern hybridization. pEST4011 hybridized to all of the restriction fragments of pJP4 except fragments BamHI-D, HindIII$A$ and $E$ to $H$. This indicated that pEST4011 had homology with the regions of pJP4 encoding 2,4-D degradative enzymes (Fig. $2 a, b$ ). Subsequently, we cloned BamHI-C, Bam HI-F and HindIII-B fragments from pJP4 into pUC18. The preliminary location of the degradative genes on plasmid pEST4011 was determined by preparing three probes using isolated pJP4 fragments Bam $\mathrm{HI}-C l a \mathrm{I}$ (from Bam HI-C), BamHI-XhoI (from BamHI-E) and Bam HI-Eco RI (from HindIII-B). Those fragments contain $t f d C-t f d B$ (chlorocatechol 1,2dioxygenase, 2,4-DCP hydroxylase) genes, $t f d R$ (regulator), $t f d C$ (chlorocatechol 1,2-dioxygenase) genes and tfdA (2,4-D monooxygenase), tfdS (regulator) genes respectively (Perkins et al., 1990). All of these fragments of pJP4 hybridized with the BamHI-B restriction fragment of pEST4011, thus indicating that catabolic genes for 2,4-D degradation are located on pEST4011 in the $10.5 \mathrm{kbp}$ Bam HI-B fragment.

\section{Localization of tfd genes in pEST4011}

Plasmid pEST4013 was constructed by cloning the BamHI-B fragment of pEST4011 into the BamHI site of the vector plasmid pKT240.

Strain PaW85, containing pEST4013 showed inducible expression of the $t f d A$ (2,4-D monooxygenase), $t f d B(2,4-$ DCP hydroxylase) and tfdC (chlorocatechol 1,2dioxygenase) genes when 2,4-D and 2,4-dichlorophenol were used as inducers (Fig. $2 b$ ).

Further hybridization experiments are summarized in Fig. $2 a, b$. The hybridization of the $2 \cdot 1 \mathrm{kbp} \mathrm{SalI-BamHI}$ (tfdB, 2,4-DCP hydroxylase) and the $1.6 \mathrm{kbp} H$ indIII fragment of $\mathrm{pJP} 4$, which contains the $t f d C$ (chlorocatechol 1,2-dioxygenase) and a part of the tfdD (chloromuconate cycloisomerase) gene only with the same $2.5 \mathrm{kbp} X h o \mathrm{I}$ fragment of pEST4013 shows that the $t f d B$ and $t f d C$ genes in pEST4011 are more closely located as compared with the corresponding genes of pJP4. The $1.0 \mathrm{kbp}$ Bam HI-XhoI fragment of pJP4, which contains the $t f d R$ (regulator) gene hybridized only to the $1.0 \mathrm{kbp}$ BamHI-XhoI fragment of pEST4013. Hybridization was also detected between the cloned $1.5 \mathrm{kbp}$ Eco RI-BamHI fragment of pJP4, which contains the $t f d A(2,4-\mathrm{D}$ monooxygenase) and part of the $t f d S$ (regulator) gene and the $2.7 \mathrm{kbp}$ HindIII fragment of pEST4013.

The $7.8 \mathrm{kbp} E c o \mathrm{RI}-$ Bam HI fragment from BamHI-B of pEST4011 was subcloned into the vector plasmid pKT240 to give pEST4014. The $t f d A$ locus is either absent or defective in this plasmid as no 2,4-D monooxygenase $(t f d A)$ activity could be detected in PaW85 (pEST4014). However, 2,4-DCP hydroxylase $(t f d B)$ and chlorocatechol 1,2-dioxygenase $(t f d C)$ activities were inducible in this strain (Fig. 2b). This revealed that the regulatory genes $t f d R$ and $t f d S$ are present on the $7.8 \mathrm{kbp} E c o \mathrm{RI}-B a m \mathrm{HI}$ fragment.

The $4.5 \mathrm{kbp} \mathrm{KpnI-BamHI}$ fragment from pEST4013 was subcloned into pKT240 to give pEST4015. Chlorocatechol 1,2-dioxygenase $(t f d C$ ) was inducible in PaW85 (pEST4015) when 2,4-DCP was used as an inducer, whereas no 2,4-DCP hydroxylase $(t f d B)$ activities was detected (Fig. 2b). The regulatory gene, $t f d S$, must therefore be located somewhere left from KpnI-BamHI $(4.5 \mathrm{kbp})$ in the EcoRI-BamHI $(7.8 \mathrm{kbp})$ fragment.

The $2.5 \mathrm{kbp} X$ XhoI fragment from pEST4013 was subcloned into pKT240 to give pEST4016. Strain PaW85(pEST4016) exhibited uninducible expression of chlorocatechol 1,2-dioxygenase $(t f d C)$ activity and no 2,4-DCP hydroxylase ( $t f d B$ ) activity (Fig. 2b). This suggests that the regulatory gene, $t f d R$, is located at the right-end of the $10.5 \mathrm{kbp} \mathrm{BamHI}$ fragment in pEST4013.

\section{Discussion}

In this report we have characterized a new 2,4-D plasmid pEST4002 determining catabolism of 2,4-D and 3-CBA. This plasmid originated from Pseudomonas sp. EST4002 isolated from soil in Estonia (Ausmees \& Heinaru, 1990). The size $(70 \mathrm{kbp})$ and restriction pattern of the derived plasmid pEST4011 (Fig. 1) differed considerably from those of pJP4 previously reported in Alcaligenes eutrophus JMP134 (Don \& Pemberton, 1985; Harker et al., 1989).

Loss of the 2,4-D $\mathrm{D}^{+}$and 3-CBA ${ }^{+}$phenotype in EST4011 occurred at a high frequency and spontaneously by the deletion of approximately $42 \mathrm{kbp}$ of DNA (Fig. 1). One possible mechanism for specific excision is reciprocal recombination between two DNA sequences present as direct repeats at the end of the excised region. If there are more than two repeats present on the plasmid molecules, the deleted sequence will be determined by the recombination switch points between specific repeats. pJP4 contains three such direct repeats (Ghosal et al., 1985) and undergoes deletions of a 15 to $18 \mathrm{kbp}$ segment when selected for growth on 3-CBA alone (Ghosal et al., 1985), and about $40 \mathrm{kbp}$ are deleted with the loss of growth on 2,4- $\mathrm{D}^{+}$and 3-CBA ${ }^{+}$(Don \& Pemberton, 1985). A similar situation may be the case for pEST4011, in which the loss of the 2,4- $\mathrm{D}^{+}$and $3-\mathrm{CBA}^{+}$phenotypes occurs by the excision of a $42 \mathrm{kbp}$ sequence.

It is interesting to note that pEST4011 showed homology only with the regions coding for the degradative genes $(t f d A-F)$ and regulatory genes $t f d S$ and $t f d R$ 

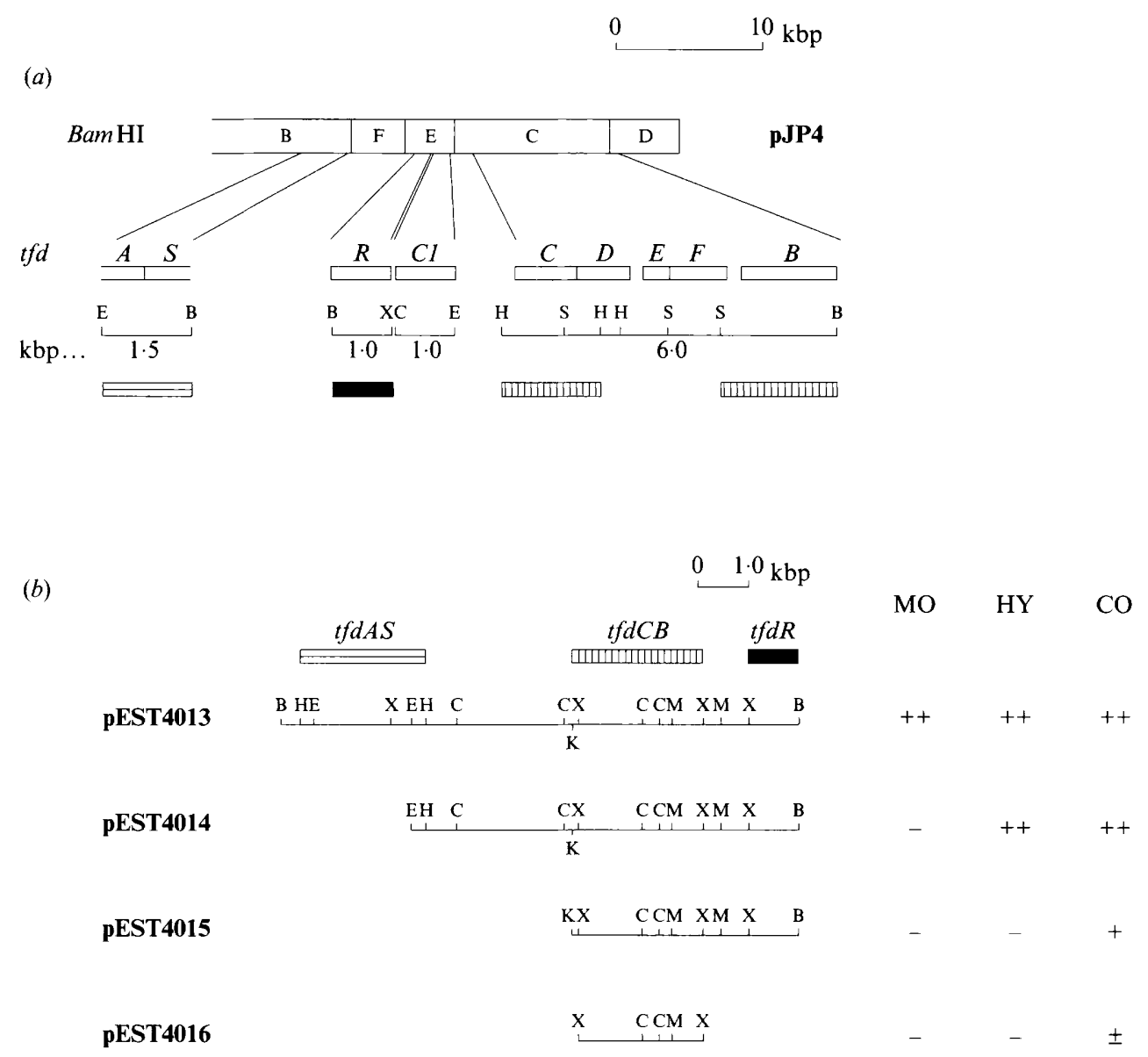

Fig. 2. (a) Map of pJP4 based on data from Kaphammer et al. (1990) and Perkins et al. (1990). The approximate locations of $t f d A$, $t f d S, t f d R, t f d C D E F$ and $t f d B$ are shown. (b) Cloning of DNA fragments of pEST4011 in P. putida PaW85 using the broad-host-range vector pKT240. Relevant restriction sites of pEST4011 DNA fragments used for cloning are shown for the $10.5 \mathrm{kbp}$ Bam HI fragment (B, BamHI; C, ClaI ; E, EcoRI; H, HindIII; K, KpnI; M, MluI; S, SalI; X, XhoI). Each plasmid listed on the left was subcloned from pEST4013 (pKT240 carrying the $10.5 \mathrm{kbp}$ BamHI-B fragment of pEST4011). The fragments of pEST4013 hybridizing with the pJP4 fragments containing $t f d A$ and $t f d S(\boxminus), t f d R(\mathbb{\square})$, and $t f d C, D, B(\mathbb{W})$ are shown. Expression of $t f d$ genes in $P$. putida PaW85 is shown on the right: MO, 2,4-dichlorophenoxyacetic acid monooxygenase activity; HY, 2,4-dichlorophenol hydroxylase activity; CO, chlorocatechol 1,2-dioxygenase activity. ++ , strong inducible activity; + , inducible activity; \pm , uninducible activity; - , no activity. By the terms 'inducible' and 'uninducible' we mean the following: in an inducible system the enzyme activities differ at least fivefold when an inducer compound is used or not; in the uninducible system the enzymes exhibit a low constitutive level of expression independent of the presence or absence of the inducer.

of pJP4. This supports other evidence that 2,4-D degradative plasmids demonstrate appreciable homology between the genes encoding enzymes that catalyse the same steps in breakdown of 2,4-D and related compounds (Chaudhry \& Huang, 1988).

By using DNA-DNA hybridization, DNA cloning techniques and enzyme assays we established the location of at least three catabolic genes encoding the first three steps in the 2,4-D degradation pathway: 2,4-D monooxygenase $(t f d A), 2,4-\mathrm{D}$ dichlorophenol hydroxylase $(t f d B)$ and chlorocatechol 1,2-dioxygenase $(t f d C)$ on the $10.5 \mathrm{kbp} \mathrm{BamHI-B}$ fragment of pEST4011. On the basis of hybridization with the $t f d R$ probe from $\mathrm{pJP} 4$ and the results of gene expression from pEST4015 and pEST4016, we have assigned the $t f d R$ gene to the right- hand of the BamHI-B fragment of plasmid pEST4011 (Fig. 2b). Testing enzyme activities in pEST4014 and pEST4015 verified the location of the second regulatory gene, tfdS needed for the inducible expression of 2,4$\mathrm{DCP}$ hydroxylase, the product of gene $t f d B$. It is possible that this regulator could be an analogue for $t f d S$ present in $\mathrm{pJP} 4$.

In spite of the strong homology between catabolic and regulatory genes of 2,4-D pathways in pJP4 and pEST4011, the order of these genes on the two plasmids is completely different (Fig. $2 a, b$ ). A further comparative study of the nucleotide sequence of catabolic genes in pEST4011, pJP4 and related plasmids would widen our understanding of the unique differences and evolutionary relationship between different 2,4-D degradative plas- 
mids in strains isolated from different geographical regions of the world.

We thank P. A. Broda and P. A. Williams for critical reading of the manuscript. A. eutrophus JMP134(pJP4) was the gift of H.-J. Knackmuss.

\section{References}

Amy, P. S., Schulke, J. W., Frazier, L. M. \& Seidler, R. J. (1985). Characterization of aquatic bacteria and cloning of genes specifying partial degradation of 2,4-dichlorophenoxyacetic acid. Applied and Environmental Microbiology 49, 1237-1245.

Ausmees, N. R. \& Heinaru, A. L. (1990). New plasmids of herbicide 2,4-D degradation. Genetika 26, 770-772 (in Russian).

Bagdasarian, M. \& Timmis, K. N. (1982). Host vector systems for gene cloning in Pseudomonas. Current Topics of Microbiology and Immunology 96, 46-67.

Bagdasarian, M. M., Amann, E., Lurz, R., Rueckert, B. \& Bagdasarian, M. (1983). Activity of the hybrid trp.lac(tac) promotor of Escherichia coli in Pseudomonas putida. Construction of broad-host-range controlled-expression vectors. Gene 26, 273-282.

BAUChop, T. \& ELSDEN, S. R. (1960). The growth of microorganisms in relation to their energy supply. Journal of General Microbiology 23, 469-495.

Bayley, S. A., Duggleby, C. J., Worsey, M. J., Williams, P. A., Hardy, K. G. \& BRODA, P. (1977). Two modes of loss of the TOL function from Pseudomonas putida mt-2. Molecular and General Genetics 154, 203-204.

BRADFORD, M. (1976). A rapid and sensitive method for the quantitation of microgram quantities of protein utilizing the principle of protein-dye binding. Analytical Biochemistry 72, 248-254.

Chaudhry, G. R. \& Huang, G. H. (1988). Isolation and characterization of a new plasmid from Flavobacterium sp. which carries the genes for degradation of 2,4-dichlorophenoxyacetate. Journal of Bacteriology 170, 3897-3902.

Connors, M. A. \& Barnsley, E. A. (1982). Naphthalene plasmids in Pseudomonas. Journal of Bacteriology 91, 1140-1154.

Ditzelmüller, G., Michael, L. \& Streichsbier, F. (1989). Isolation and characterization of a 2,4-dichlorophenoxyacetic acid-degrading soil bacterium. Applied Microbiology and Biotechnology 31, 93-96.

Don, R. H. \& Pemberton, J. M. (1981). Properties of six pesticide degradation plasmids isolated from Alcaligenes eutrophus and Alcaligenes paradoxus. Journal of Bacteriology 145, 681-686.

Don, R. H. \& Pemberton, J. M. (1985). Genetic and physical map of the 2,4-dichlorophenoxyacetic acid-degradative plasmid pJP4. Journal of Bacteriology 161, 466-468.

Don, R. H., Weightman, A. J., Knackmuss, H. J. \& Timmis, K. N. (1985). Transposon mutagenesis and cloning analysis of the pathways for degradation of 2,4-dichlorophenoxyacetic acid and 3- chlorobenzoate in Alcaligenes eutrophus JMP134(pJP4). Journal of Bacteriology 161, 85-90.

Downing, R. \& BRodA, P. A. (1979). Cleavage map of the TOL plasmid of Pseudomonas putida mt-2. Molecular and General Genetics 177, 189-191

Ghosal, D. \& You, I.-S. (1988). Nucleotide homology and organization of chlorocatechol oxidation genes of plasmid pJP4 and pAC27. Molecular and General Genetics 211, 113-120.

Ghosal, D. \& You, I.-S. (1989). Operon structure and nucleotide homology of the chlorocatechol oxidation genes of plasmids pJP4 and pAC27. Gene 83, 225-232.

Ghosal, D., You, I.-S., Chatterjee, D. K. \& Chakrabarty, A. M. (1985). Plasmids in the degradation of chlorinated aromatic compounds. In Plasmids in Bacteria, pp. 667-686. Edited by D. R. Helinski, S. N. Cohen, D. B. Clewell, D. A. Jackson \& A. Hollaender. New York: Plenum Press.

Gibson, T. J. (1984). Studies on the Epstein-Barr virus genome. $\mathrm{PhD}$ thesis, Cambridge University, Cambridge (UK).

HaGeman, G. D. (1966). Synthesis of the enzymes of the mandelate pathway by Pseudomonas putida. I. Synthesis of the enzymes by the wild-type. Journal of Bacteriology 91, 1140-1154.

HaNAHAN, D. (1983). Studies on transformation of $E$. coli with plasmids. Journal of Molecular Biology 166, 577-580.

HANSEN, J. E. \& OlsEN, R. H. (1978). Isolation of large bacterial plasmids and characterization of the P2 incompatibility group plasmids pGM1 and pGM5. Journal of Bacteriology 135, 227-238.

Harker, A. R., Olsen, R. H. \& Seidler, R. J. (1989). Phenoxyacetic acid degradation by the 2,4-dichlorophenoxyacetic acid (TFD) pathway of plasmids pJP4: mapping and characterization of the TFD regulatory gene $t f d R$. Journal of Bacteriology 171, 314-320.

KAPHAMMER, B. \& OlseN, R. H. (1990). Cloning and characterization of $t f d S$, the repressor-activator gene of $t f d B$, from the 2,4dichlorophenoxyacetic acid catabolic plasmid pJP4. Journal of Bacteriology 172, 5856-5862.

Kaphammer, B., KukoR, J. J. \& Olsen, R. H. (1990). Regulation of $t f d$ CDEF by $t f d R$ of 2,4-dichlorophenoxyacetic acid degradation plasmid pJP4. Journal of Bacteriology 172, 2280-2286.

Maniatis, T., Fritsch, E. F. \& Sambrook, J. (1982). Molecular Cloning. A Laboratory Manual. Cold Spring Harbor, NY: Cold Spring Harbor Laboratory.

Pemberton, J. M. \& Fisher, P. R. (1977). 2,4-D plasmids and persistence. Nature, London 268, 732--733.

Perkins, E. J., Gordon, M. P., Caceres, D. \& Lurquin, P. F. (1990) Organization and sequence analysis of the 2,4-dichlorophenol hydroxylase and dichlorocatechol oxidative operons of plasmid pJP4. Journal of Bacteriology 172, 2351-2359.

Pierce, G. E., Facklam, T. J. \& Rice, J. M. (1981). Isolation and characterization of plasmids from environmental strains of bacteria capable of degrading the herbicide 2,4-D. Developments in Industrial Microbiology 22, 401-408.

Southern, E. M. (1975). Detection of specific sequences among DNA fragments separated by gel electrophoresis. Journal of Molecular Biology 98, 503-517.

Yanisch-Perron, C., Vieira, J. \& Messing, J. (1985). Improved M13 phage cloning vectors and host strains: nucleotide sequences of the M13 mp18 and pUCl9 vectors. Gene 33, 103-119. 